\title{
Formation of Adult Lay Catholics for Commitment in the World
}

\begin{abstract}
The teaching of the Second Vatican Council develops an understanding of the Church as an integral entirety, present in the world and operating in accordance with its nature and purpose. Every personal commitment of a lay faithful, every effort made and each achievement has an impact on others and the whole Church. However, the commitment of adult Catholics to the world requires their appropriate preparation. Therefore, this article will first present the ecclesiological foundations of the lay faithful's earthly commitment, and then, the process of their preparation, taking into consideration their personal and religious development. Finally it will also explore the meaning of the community as the place of their permanent formation.
\end{abstract}

\section{Keywords}

Lay faithful, formation, commitment to the world.

"Because of the very economy of salvation the faithful should learn how to distinguish carefully between those rights and duties which are theirs as members of the Church, and those which they have as members of human society. Let them strive to reconcile the two, remembering that in every temporal affair they must be guided by a Christian conscience, since even in secular business there is no human activity which can be withdrawn from God's dominion. In our own time, however, it is most urgent that this distinction and also this harmony should shine forth more clearly than ever in the lives of the faithful, so that the mission of the Church may correspond more fully to the special 
conditions of the world today. For it must be admitted that the temporal sphere is governed by its own principles, since it is rightly concerned with the interests of this world."' The lay faithful's daily commitment to spread the Kingdom of God lays down a requirement of both recalling the ecclesiological foundations of such involvement and appropriate preparation for the completion of this task. Therefore, this article will first present the foundations of the lay faithful's temporal commitment, taking account of the diversity of their functions and tasks related to the Church as an integral entirety. Then, we will present the process of the laity's preparation, taking into consideration their personal and religious development, and the meaning of a community as the place of their permanent formation.

\section{Ecclesiological foundations of earthly commitment of Church members}

The Church, which is, in Christ, like a sacrament, or as a sign and instrument both of a very closely knit union with God and of the unity of the whole human race $^{2}$, continues - in time and space - God's plan of salvation, redemption and sanctification. The Church, at the will of its Founder, presents itself also as "the People of God", that is, as the humankind introduced again into God's plan and called to live among people as a leaven so that all achieve unity. All will become the People of God, the redeemed humankind. Just as in the Old Testament, God had His people - Israel, in the New Testament, Christ creates His people. Through these "new people" consisting of those who through faith and sacraments are implanted in Him, Christ acts among individuals so that the fruits of redemption will disseminate across the world. In this way, the Church the redeemed people - is becoming a sign of redemption to be fulfilled. ${ }^{3}$

Therefore, we may describe the Church as sacramentum renovationis totium mundi - the mystery of a renewal of the whole world. For the world is the place where the mission of the Church is being accomplished. However, it is worth remembering that by no means should the existence of the Church in the world

${ }^{1}$ Lumen gentium 36.

${ }^{2}$ Lumen gentium 1.

${ }^{3}$ Cf. G. Lazzati, Świeccy a chrześcijańskie zaangażowanie w sprawy doczesne, Warszawa 1988, pp. 56-57. 
be understood as ruling the world or as separation from the world or even more as being at the world's disposal. According to Jesus Christ's intention, the Church is a reality called from its very nature to love the world and to serve it through bringing out Christ's grace from within the world. Through this grace, people who decide to accept Jesus Christ, become revived and freed by Him from sins so that they will be able to arrange the whole reality in accordance with God's intention. ${ }^{4}$ The Church, of its very nature, is missionary, that is, regularly sent to the world so that - when living in the world, with the world and for the world but not being the world - it will be salt and leaven of this mystery of redemption.

\subsection{The Church as an integral entirety}

The teaching of the Second Vatican Council develops the understanding of the Church as an integral entirety present in the world and acting in accordance with its nature and purpose. Every personal commitment of a lay faithful, every effort made and each achievement has an impact on others and the whole Church. Therefore, the Church is not an anonymous community but a supernatural fellowship of people who, with Christ and in Christ, receive a new life and serve the whole Body of Christ. ${ }^{5}$ An internal unity is characteristic for the mystery of the Church as all members of "the people of the saved" are connected with each other by the common foundation (baptism and confirmation) and the common purpose (a universal call for sanctity) ${ }^{6}$

From the common origin and purpose stems a deep and inalienable bond of unity that joins members of the People of God and creates, from them, a single mystical person - Jesus Christ's Bride. The Church as a universal sacrament of salvation is constantly sent to the world where the people of the One who was saved becomes the saving people. Because of its origin and mission, one can see a double tension in the Church which constantly places it in the situation of continuously going beyond itself. If the Church wants to be itself, to go continuously beyond itself, coming closer to the Lord whose Bride it is, it needs to always go wherever the Groom wants her to go, while serving Him in obedient love. Therefore, each Christian should be faithful to the law of sanctity and love.

${ }^{4}$ Cf. G. Lazzati, Świeccy a chrześcijańskie zaangażowanie w sprawy doczesne, pp. 54-57.

${ }^{5}$ Cf. A. L. Szafrański, Kariologia. Zarys nauki o Kościele w świecie współczesnym, Lublin 1990, p. 245.

${ }^{6}$ Cf. M. de Merode, Theology of the Laity Today, "Lumen vitae"42 (1987) No. 2, pp. 141-143. 


\subsection{Diversity of functions in the Church}

The mystery of the salvific mission of the Church is revealed also in the fulfilment and entrustment of various services and offices. ${ }^{7}$ Two functions manifest themselves in the Church: a typically hierarchical and a typical lay. These functions, which create the structure of the Church, in their specificity and complementarity, not only do not undermine the ecclesial unity or create dualisms (the Church of the clergy versus the Church of the lay people), but together express the bipolar mystery of turning to Jesus Christ and to the world, through which the Church accomplishes the mission of saving the world, entrusted to it by Christ. ${ }^{8}$

The lay people, baptized and confirmed, in the nature of these sacraments have powers that enable and oblige them to receive and distribute sacraments (baptism - in urgent cases, marriage - as a rule), co-celebrate the Eucharistic sacrifice and exercise the apostolate. ${ }^{9}$ Two functions - priestly and lay - are subjected to each other, one serves the other. In fact, thanks to one of them the priestly function - people are freed from sin, regaining in Jesus Christ the likeliness of children. This allows them - if they remain faithful - to step forward in the obedience to the Creator, acting - and here we touch the other function - among earthly things with which, on the basis of their calling, they are bound by the plan of salvation. ${ }^{10}$

The sanctification of the world, as the work of the whole Church, happens on a triple plane: preaching the Gospel, sacral and sacramental, and the plane of humanization and Christianisation of the world and its structures. On the first two planes sanctification is entrusted predominantly to priests and bishops, while on the third - to lay people ${ }^{11}$. This is recalled in the documents of the Second Vatican Council: "Secular duties and activities belong properly although not exclusively to laymen. Therefore acting as citizens in the world, whether individually or socially, they will keep the laws proper to each discipline, and labour to equip themselves with a genuine expertise in their various fields. They will gladly work with men seeking the same goals. Acknowledging the

${ }^{7}$ Cf. A. L. Szafrański, Kariologia..., p. 246.

${ }^{8}$ Cf. G. Lazzati, Świeccy a chrześcijańskie zaangażowanie w sprawy doczesne, ...p. 58.

9 Cf. A. L. Szafrański, Kariologia..., p. 246.

${ }^{10}$ Cf. G. Lazzati, Świeccy a chrześcijańskie zaangażowanie w sprawy doczesne..., pp. 61-63.

${ }^{11}$ Cf. R. Goldie, Świeccy, laikat, świeckość, Warszawa-Poznań 1991, p. 12. 
demands of faith and endowed with its force, they will unhesitatingly devise new enterprises, where they are appropriate, and put them into action. Laymen should also know that it is generally the function of their well-formed Christian conscience to see that the divine law is inscribed in the life of the earthly city... Since they have an active role to play in the whole life of the Church, laymen are not only bound to penetrate the world with a Christian spirit, but are also called to be witnesses to Christ in all things in the midst of human society"12.

\subsection{Commitment of lay people}

"The laity must take up the renewal of the temporal order as their own special obligation. Led by the light of the Gospel and the mind of the Church and motivated by Christian charity, they must act directly and in a definite way in the temporal sphere. As citizens they must cooperate with other citizens with their own particular skill and on their own responsibility. Everywhere and in all things they must seek the justice of God's kingdom. The temporal order must be renewed in such a way that, without detriment to its own proper laws, it may be brought into conformity with the higher principles of the Christian life and adapted to the shifting circumstances of time, place, and peoples. Preeminent among the works of this type of apostolate is that of Christian social action which the sacred synod desires to see extended to the whole temporal sphere, including culture." ${ }^{13}$ The lay function obliges the lay faithful not only to be present in the world but also to take responsibility for the temporal order. It is just this particular assumption of responsibility for ordering the early reality according to the plan of God, which defines the identity of the lay faithful in the Church. ${ }^{14}$ The ecclesiological foundation of the earthly commitment shows that it is a unique task of lay Christians who are called with the power of God's calling to commit themselves to the benefit of man (in a community with all humans), to ordering the whole earthly reality. The Church offers them, as Christians, an ability to fulfil this command given by God to people.

This commandment given to all people directly by God as a law being their human calling, in view of the appearance of the sin, may be fulfilled only by new man revived in Jesus Christ and persisting in the Church. The fathers of

12 Gaudium et spes 43.

13 Apostolicam actuositatem 7.

${ }^{14}$ Cf. M. de Merode, Theology of the Laity Today..., p. 142. 
the Second Vatican Council reminded: "The laity, by their very vocation, seek the kingdom of God by engaging in temporal affairs and by ordering them according to the plan of God. They live in the world, that is, in each and in all of the secular professions and occupations. They live in the ordinary circumstances of family and social life, from which the very web of their existence is woven. They are called there by God that by exercising their proper function and led by the spirit of the Gospel they may work for the sanctification of the world from within as a leaven. In this way they may make Christ known to others, especially by the testimony of a life resplendent in faith, hope and charity. Therefore, since they are tightly bound up in all types of temporal affairs it is their special task to order and to throw light upon these affairs in such a way that they may come into being and then continually increase according to Christ to the praise of the Creator and the Redeemer." ${ }^{15}$ Therefore, in the economy of creation, salvation and sanctification of the world, the world is for a lay Christian not only a sociological but also a theological place. It is a place where a person's identity becomes full, in the sense that he/she, as new person, is entrusted - as the Church's subject - with a new task, a specific mission to be fulfilled in that place. $\mathrm{He} /$ she has to be a leaven in it, has to be accountable for using all the natural and supernatural talents he/she has, so as to manage the world according to the plan of God, in obedience to the Creator, under the guidance of the Holy Spirit while respecting the autonomy of the earthly realities.

\section{Preparation of lay Catholics}

In order to live in the world prudently, responsibly and according to the assumptions of the Catholic social thought, a lay Catholic needs regular formation which can be undergone through adult catechesis. Its basic and specific objective is both religious and personal formation, as well as accompanying man at all stages of development since religious formation is always in direct connection with the general development of man. It is only in view of the general development of man that faith manifests as a value which transmits a specific concept of life and has an influence on broadly taken social and cultural life. ${ }^{16}$

${ }^{15}$ Lumen gentium 31.

${ }^{16}$ Cf. K. Misiaszek, Katecheza dorosłych $w$ dokumentach Kościoła, in: Katecheza dorosłych we wspólnocie Kościoła, ed. K. Misiaszek, Warszawa 2002, pp. 36-37. 
A mature Catholic, despite the changing circumstances of family, social and professional life, is capable of taking prudent and responsible decisions.

\subsection{Personal development of adults}

Considering formation of adults from the perspective of their development, we must not forget that the true nature of that formation is revealed exactly in the context of continuous developmental dynamics of an adult. Contemporary psychology proves that an adult is not necessarily personally mature. The process of achieving this maturity is only the subject of a continuous quest inscribed into man's mental nature. This task of constant improvement and coming into being becomes particularly important in the religious sphere. Based on the example of religious infantilism, typical for people with immature personality, or the example of apostates for whom unbelief may result from taking a mature decision, ${ }^{17}$ we can clearly see adirect reliance of the growth of faith on the degree of personal development. We can also see that personal development is closely connected with the growth of faith, makes it conditional and somewhat anticipates it. In this sense, care for appropriate personal development will be the foundation of adult catechesis, providing its sense and meaning. One of the first tasks of adult catechesis can be described as accompanying persons in their struggle for personal perfection, which manifests for Christians not only as a task but also a duty that arises from the call to live life to the full, namely sanctity. ${ }^{18}$ Man's formation cannot take place without anthropology, thanks to which faith and culture permeate each other.

The formation of adult Christians - wanting to prepare them to commitment to the world and to shape as mature Christians - should therefore set for itself as a goal "a comprehensive, integral and concurrent formation of a person and their faith." ${ }^{19}$ Therefore, mature faith can be available exclusively to a mature person who can - as the only one - fully, creatively and responsibly undertake actions arising from a Christian vocation. "The faith of adults, therefore, must be continually enlightened, developed and protected, so that it may acquire that

17 Cf. D. Kurzydło, Koncepcja katechezy dorosłych we wspótczesnych dokumentach Kościoła, Kraków 2003, p. 109-112; G. Allport, Osobowość a religia, Warszawa 1988, pp. 49. 72-76.

18 Cf. Populorum Progressio 16; Directorium Catechisticum Generale 94; K. Misiaszek, Katecheza dorosłych $w$ dokumentach Kościoła..., pp. 41-42.

19 K. Misiaszek, Katecheza dorostych w dokumentach Kościoła..., p. 44. 
Christian wisdom which gives sense, unity, and hope to the many experiences of personal, social, and spiritual life." ${ }^{20}$

\subsection{Shaping mature religiousness of adults}

Mature religiousness, in the process of stepping towards eschatological fullness, is directly dependent on personal maturity. ${ }^{21}$ However, the dependence is mutual. Because faith, being "one of the most important developmental dynamics," 22 helps in self-actualization that gives sense to human existence. It supports the shaping of inner unity and harmony with oneself and the world. One can say that it is the foundation of, not only multidirectional but also full and integral, human development. Maturity of faith consists of its two forms: "actual maturity (achievable on each stage of human life) and eschatological maturity," ${ }^{23}$ that is sanctity, whereas the attainment of sanctity depends directly on maturity of faith on successive developmental stages of actual maturity. In this way, faith manifests itself as the foundation of the ultimate communion with Jesus Christ.

The development of faith begins in the mystery of baptism, when the grace of faith is engrafted into man. It is continued in the community of the Church and strengthened with the grace of other sacraments. The Church, recognizing the diversification of degrees of man's developmental processes on the plane of faith, duties and life tasks, undertakes regular adult formation. To this end, it sets up for itself a task of shaping appropriate attitudes through fostering the faith already known, and developing liturgical, moral and prayer formation. ${ }^{24}$ The maturity of attitudes is a test of faith in various crisis situations ${ }^{25}$ and allows us to perfect our way of life.

${ }^{20}$ Cf. General Directory for Catechesis 173.

${ }^{21}$ Cf. G. Allport, Osobowość a religia..., p. 78.

${ }^{22}$ G. Allport, Osobowość a religia..., p. 170.

${ }^{23}$ D. Kurzydło, Koncepcja katechezy dorosłych we współczesnych dokumentach Kościoła..., p. 163.

${ }^{24}$ Cf. General Directory for Catechesis 86-87; Directorium Catechisticum Generale 30; Catechesi tradendae 39; Christifideles laici 58; P. Purnell, Our Faith Story. Its Telling and Its Sharing. An Education in Faith, London 1991, p. 98.

${ }^{25}$ Cf. A. Kiciński, Dorosły jako podmiot katechezy, in: Katecheza dorosłych we wspólnocie Kościoła, ed. K. Misiaszek, Warszawa 2002, pp. 149-153; D. Kurzydło, Koncepcja katechezy dorosłych we współczesnych dokumentach Kościoła..., pp. 176-185. 
The Church, however, pays attention to the fact that the direct foundation for shaping appropriate attitudes and a mature faith is the person's own motivation, ${ }^{26}$ giving him/her a direction and fully-free development. It is only faith resulting from motivation that gives readiness for activity, an opportunity to change one's life. Faith, setting a course towards "the state of the 'perfect man,' and (...) maturity in the fullness of Christ," ${ }^{\prime 27}$ gives sense to life. Adult formation, which through offering an opportunity of conversion, invites us to participate in the plan of salvation, is to help us discover this new sense of life. While incentivizing the faithful, it helps them accept the grace of following Jesus and brings them closer to communion with Him. However, all of this is possible owing to wisdom of the Church that achieves its objective through the affirmation of human freedom which is the foundation of faith. ${ }^{28}$

For Christians, freedom is the value owing to which a personal encounter with God and man can take place, which conditions mature faith. The meaning of freedom, in pursuit of the Kingdom, is highlighted by Jesus Christ Himself who heals man from everything that undermines their freedom..$^{29}$ Jesus Christ, through the redemption of man's spiritual powers, through granting them freedom again, enables them to make friendship with God, to the communion that is a climax of a Christian's life. The decision to follow Jesus is not the result of a one-off act of will but hardship of a continuous effort. The task of formation of the adult faithful is not about broadening religious knowledge but rather about the discovery, acquisition and shaping of faith relations and dynamism,

${ }^{26}$ Cf. E. Młyńska, Katecheza dorosłych we Francji, in: Katecheza dorosłych we wspólnocie Kościoła, ed. K. Misiaszek, Warszawa 2002, p. 277-304; E. Osewska, Praktyka katechezy rodzinnej na świecie, "Więź" 5 (1988), pp. 161-171; J. Kochel, Katecheza dorosłych w Kościele mediolańskim, in: Katecheza dorosłych we wspólnocie Kościoła, ed. K. Misiaszek, Warszawa 2002, pp. 305-331; J. Stala, Die Werteerziehung im Lehrwerk Johannes Pauls II., „The Person and the Challenges“ 6 (2016) Nr 1, pp. 17-27; J. Stala, Der Beitrag des Menschenbilds von Johannes Paul II. zu einer Werteerziehung, die auf das Leben in der Familie, der Gesellschaft und der Kirche vorbereitet, „Analecta Cracoviensia” 48 (2016), pp. 163-175; J. Stala, Die Erziehungsmission der Familie: Aktuelle Herausforderungen und neue Konzeptionen, „The Person and the Challenges“ 7 (2017) Nr 1, pp. 133-147.

27 General Directory for Catechesis 56.

${ }^{28}$ Cf. P. Purnell, To be a People of Hope. Adult Education: A Christian Perspective, London 1987, p. 20.

${ }^{29}$ Cf. Mt 11:5. 
a multi-aspect presentation of the Mystery of Jesus Christ and commitment to the world in accordance with His guidelines. ${ }^{30}$

\section{A community as a place of permanent adult formation}

A desire to pervade the earthly reality with Christin principles, virtues and faith presents a Catholic with a challenge to start permanent formation. Therefore, formation aimed at mature commitment to the world requires care to ensure mature Christian communities.

\subsection{Building mature Christian communities}

In view of the growing laicization of the world and the development of post-modern society, we can see the necessity of building mature Church communities that will support Christians in their development. Moreover, building a community, as the basic form of the actualization of the Church in the world, is for the Church a sign of hope heralding an increase of opportunities to disseminate its teaching. ${ }^{31}$ An opportunity to consummate this hope of the Church is connected with man's endeavour to meet the need of establishing deep interpersonal ties and relations. Its consummation is one of the tasks of Church communities as well as a condition of maturity, both personal and communal, ${ }^{32}$ as man lives in diverse bonds thanks to which he/she can develop themselves to their fullness.

The prerequisite of establishing a community is the deliberate and voluntary consent to affiliation and specific assignment. This consent of will and its subjects constitute the basis for existence of each community and the foundation for values that are connected with participation in the life of these communities: "The disciples of Christ gather together in them so as to hear the word of God, to develop fraternal bonds, to celebrate the Christian mysteries in their lives and to assume responsibility for transforming society. In addition to these specifically Christian concerns other important human values emerge: friendship, personal

${ }^{30}$ Cf. Familiaris consortio 9; Catechesi tradendae 5.20; Dives in misericordia 13; Apostolicam actuositatem 4; Lumen gentium 25; 170; P. Purnell, To be a People of Hope..., p. 20; D. Kurzydło, Koncepcja katechezy dorosłych we wspótczesnych dokumentach Kościoła..., p. 95.

${ }^{31}$ Cf. Lumen gentium 12, 32; Catechesi tradendae 15.

${ }^{32}$ Cf. J. Szpet, Inicjacyjna funkcja katechezy, "Horyzonty Wychowania” 7 (1996) 3, p. 64. 
recognition, a spirit of co-responsibility, creativity, vocational response, concern for the problems of the world and of the Church."33 The enriching community experiences are expressed not only in building unity ${ }^{34}$ among its members but also contribute to the development of Christian maturity. "Therefore, all the faithful of Christ are invited to strive for the holiness and perfection of their own proper state. Indeed, they have an obligation to so strive. Let all then have care that they guide aright their own deepest sentiments of soul. Let neither the use of the things of this world nor attachment to riches, which is against the spirit of evangelical poverty, hinder them in their quest for perfect love." ${ }^{35}$ Affiliation to a community plays a crucial role also in the process of building communion with Jesus Christ living in it. Communion with God, as well as unity of Church members, are the main pillars of Christian communities. ${ }^{36}$ The building block of these pillars is love, since it is only because of it that true bonds, willingness to share and being a gift to others are established. ${ }^{37}$ The desire of love and communion that gives the sense of fullness of life, is inscribed in the heart of each person. In this way, building communities appears as the objective that serves personal development of their members and - through it - also the renewal of the world. Building a mature community requires from its members their own commitment, motivation and time. The personal activity of man, who contributes to common efforts through participation in searching, dialogue and exchange of different points of view, contributes to development of catechetical impacts. Thanks to that activity, the mission of the Church in the world is more fully accomplished. The indispensable source of the apostolate of the community are also charisms given to each member by the Holy Spirit, which encourage to undertake different ministries and tasks. These unique gifts, being a testimony to diversity of the community members, at the same time, incorporate them into the mission of serving others, building out of them a complete entirety and contributing to common good. ${ }^{38}$

${ }^{33}$ General Directory for Catechesis 263.

${ }^{34}$ Cf. P. Purnell, Our Faith Story..., p. 108-109.

35 Lumen gentium 42.

${ }^{36}$ Cf. Christifideles laici 18-25; Novo millennio ineunte 42.

${ }^{37}$ Cf. Familiaris consortio 18; Gaudium et spes 24; K. Wojtyła, Miłość i odpowiedzialność, Lublin 1986, p. 42.

${ }^{38}$ Cf. General Directory for Catechesis 157; Christifideles laici 20-24; J. Stala, Uczestnictwo wiernych w dziele ewangelizacji, "Ateneum Kapłańskie" 95 (2003) No. 564, p. 222; D. Kurzydło, Koncepcja katechezy dorosłych we współczesnych dokumentach Kościoła..., pp. 104-108. 
Both Christians' activity and the charisms they have, to a different degree, through knitting the Christian community together, play an important role in building its maturity. Building mature communities ultimately depends also on taking account of its members' developmental uniqueness. Therefore, through continuous engagement in a Christian community, the lay faithful may grow and acquire skills to act in the world. From this perspective, the formation of a mature Christian community, being the beginning, the place and the purpose of adult formation, should be considered as the primary care of the Church. ${ }^{39}$

\subsection{Continuous responsibility and care for the development of a community}

Participation in the life of the Christian community is a consequence of the decision of affiliation to Jesus Christ and the desire to live a life in accordance with His guidelines. By living in the environment of the lay faithful aspiring to a common goal which is a fellowship, a deeper interiorization of the World of God into daily life takes place and the union with the Saviour is strengthened. It was already Jesus Christ Himself who, when building the Church on earth, was doing it on the basis of a community. This original intention reveals the mystery of the Church-Communion as the secret of unity that has its roots and source in the unity of the Trinity of Divine Persons. ${ }^{40}$ God, being a community of persons, wants this community for salvation of man who "is the only creature on earth which God willed for itself, cannot fully find himself except through a sincere gift of himself." ${ }^{11}$

The unity of a community that gathers in the name of the Trinity has a double meaning - eschatological and earthly. Firstly, this is unity of the striving Church, the Church in transit, the transitory Church. This is the unity of a community waiting for eschatological fullness in Jesus Christ and, so to speak, already participating in it. ${ }^{42}$ On the other hand, this is unity that gathers the faithful here and now. Thanks to an encounter with faith of other people, being meaningful

39 Cf. General Directory for Catechesis 253; Evangelii nuntiandi 23; P. Purnell, To be a People of Hope..., p. 32.

${ }^{40}$ Cf. Novo millennio ineunte 29.

${ }^{41}$ Gaudium et spes 24.

${ }^{42}$ Cf. Sacrosanctum Concilium 8; D. Kurzydło, Koncepcja katechezy dorosłych we wspótczesnych dokumentach Kościoła..., pp. 100-101. 
to their personal relations, development of faith and conversion. This is unity that embraces the Catholicity and Apostolicity of the Church. The lay faithful, as redeemed by Jesus Christ, should be aware of having a gift of participation in the mission of the Church - the gift owing to which they can change the world that surrounds them.

Mature lay Catholics provide the world with a new degree of sanctification, and they do not do it exclusively through bringing into it specifically religious signs, gestures or actions, but first of all they order it by doing their daily work and resting in faith, hope and love for the development of the Kingdom of God. Recognizing the contemporary world as a partner for dialogue and a place of sanctification, the Church approaches it being aware of constant changes taking place in it, and the interdependence between the spiritual and material spheres. An adult Catholic, participating in formation adjusted to their needs, has an opportunity to deepen their skill of defending the proclaimed values in the world, to express their faith in contemporary terms within their family, the Church and society and to build every day a culture of life, love and truth.

\section{Bibliography}

Allport G., Osobowość a religia, Warszawa 1988.

Goldie R., Świeccy, laikat, świeckość, Warszawa-Poznań 1991.

Katecheza dorosłych we wspólnocie Kościoła, ed. K. Misiaszek, Warszawa 2002.

Kiciński A., Dorosły jako podmiot katechezy, in: Katecheza dorosłych we wspólnocie Kościoła, ed. K. Misiaszek, Warszawa 2002, pp. 149-153.

Kochel J., Katecheza dorosłych w Kościele mediolańskim, in: Katecheza dorostych we wspólnocie Kościoła, ed. K. Misiaszek, Warszawa 2002, pp. 305-331.

Kurzydło D., Koncepcja katechezy dorosłych we współczesnych dokumentach Kościoła, Kraków 2003.

Lazzati G., Świeccy a chrześcijańskie zaangażowanie w sprawy doczesne, Warszawa 1988. Merode de M., Theology of the Laity Today, "Lumen vitae"42 (1987) No. 2, pp. 141-143.

Młyńska E., Katecheza dorosłych we Francji, in: Katecheza dorostych we wspólnocie Kościoła, ed. K. Misiaszek, Warszawa 2002, p. 277-304.

Osewska E., Praktyka katechezy rodzinnej na świecie, "Więź" 5 (1988), pp. 161-171.

Purnell P., Our Faith Story. Its Telling and Its Sharing. An Education in Faith, London 1991. 
Purnell P., To be a People of Hope. Adult Education: A Christian Perspective, London 1987.

Stala J., Der Beitrag des Menschenbilds von Johannes Paul II. zu einer Werteerziehung, die auf das Leben in der Familie, der Gesellschaft und der Kirche vorbereitet, „Analecta Cracoviensia” 48 (2016), pp. 163-175.

Stala J., Die Erziehungsmission der Familie: Aktuelle Herausforderungen und neue Konzeptionen, „The Person and the Challenges“ 7 (2017) Nr 1, pp. 133-147.

Stala J., Die Werteerziehung im Lehrwerk Johannes Pauls II., „The Person and the Challenges" 6 (2016) Nr 1, pp. 17-27.

Stala J., Uczestnictwo wiernych $w$ dziele ewangelizacji, “Ateneum Kapłańskie” 95 (2003) No. 564.

Szafrański A. L., Kariologia. Zarys nauki o Kościele w świecie współczesnym, Lublin 1990.

Szpet J., Inicjacyjna funkcja katechezy, "Horyzonty Wychowania” 7 (1996) 3.

Wojtyła K., Miłość i odpowiedzialność, Lublin 1986. 